\title{
GOVERNMENT SERVICE AND THE AMERICAN CONSTITUTION*
}

\author{
Davm RIESMaN, JR.†
}

7 HE importance of the American Constitution is apt to be underrated by radicals and overrated by conservatives. Students of British politics sometimes attribute the generally conceded inferiority of American administration, as compared with the British, in large measure to the American constitutional limitations. This view ascribes too much importance to the form of the constitutional restraints, for in Britain settled aristocratic traditions have served in the past as the most formidable of restraints, and the customary taboos have been effective substitutes for the legal separation of powers. ${ }^{x}$ In the United States the government is subject to a separation of powers not so much because of a long historical tradition of respect for the Constitution, but because division of power has been characteristic of our social and economic institutions. ${ }^{2}$ A free, competitive capitalism provided us with a relatively automatic dispersion of the sources of livelihood, and hence of power. ${ }^{3}$ Dispersion was also facilitated by a large freedom of association: in trade unions, corporate groups, farm co-operatives, sectarian churches, precinct clubs, and reform societies. These associations not only balanced power among competing groups in the community, but even within the individual himself, who was torn between loyalties to competing and, in Marxian terms, inconsistent memberships. I question how long the constitutional separation of powers may maintain itself in an age of monopoly capitalism

* The subject of this paper was discussed in an address, May 28, r938, before the First Annual Law Institute of the University of Buffalo School of Law. The author wishes to acknowledge the valuable suggestions of Professor Carl J. Friedrich, of Harvard University.

$\dagger$ Professor of Law, University of Buffalo.

From Montesquieu to date, observers have mistaken British theory of constitutional restrictions for actual practice.

"Many of our "constitutional" restraints-federalism, for example-crop up in labor unions, trade associations, and churches. Arbitral and other devices (publicity, consumers groups, etc.) exist for seeking a bill of rights in corporate administration; cf. Herring, Logomachy and Administration, 2 J. Soc. Phil. 95, 96-IOI (I937).

3 Power is divided in our society also because some ambitious men seek wealth (and incidentally power) in business, and others seek power (and incidentally wealth) in government, political parties, or religious organizations. 
(whether "private" or "socialist") 4 which concentrates the sources of livelihood, and in an age of social stratification which will tend to limit the psychological freedom of association. It is in the light of these forces, overlooked by conservatives, that radicals are apt to undervalue the social and economic consequences of the Constitution itself.

The Constitution, for the purposes of this paper, involves a three-fold division of powers: it separates the powers of the federal government from those of the states; the powers of the legislative, executive, and judicial branches of the federal government from each other; and the rights of the citizen from those of the government through the instrumentality of the Bill of Rights. ${ }^{5}$ I propose to examine the relation of each of these divisions to the efficiency and responsibility of government administration.

\section{I}

FEDERAIISM

The efficiency of administration, whether in business or government, depends upon the application of a rational division of labor to the tasks to be performed. ${ }^{6}$ This specialization has two consequences. In the first place, an elaborate hierarchical control is required to supervise the distribution and performance of the specialized functions of the administration. In the second place, specialization demands increasing professional training of the officials who are to assume their appointed tasks within the hierarchy. From the point of view of this analysis, federalism appears to be a serious bar to government efficiency. For, while in an ideal administration the power of officials would be divided entirely in accordance with the functions (commerce, finance, etc.) to be performed, the purpose of federalism is the regional distribution of power. ${ }^{7}$ Also, while power in a non-federal hierarchy is vested in a single individual (king, president, or pope), a federal system creates many heads of little hierarchies who com-

4 The Marxian notion that the state would disappear with the rise of the proletariat to power means only that everyone will be in the employ of the state and there will be no one to observe the state. See note $4 \mathrm{I}$ infra.

$s$ The amending process may be thought of as dividing power between the statutory and the constitutional majorities, or it may be thought of as dividing power between the people exercising their sovereign power and the people acting within the three-fold set of constitutional restraints. For discussion, see Friedrich, One Majority against Another: Populus Semper Virens, 5 South. Rev. 42 (I939).

${ }^{6}$ Friedrich, Responsible Government Service under the American Constitution, in Friedrich et al., Problems of the American Public Service I, 16-29 (1935). See Dimock, Modern Politics and Administration 39I (1937).

7 For a more differentiated analysis, see Gulick, Notes on the Theory of Organization, in Gulick and Urwick, Papers on the Science of Administration r5-38 (r937). 
pete for power. But the lack of co-operation which is so painfully evident between state and national officials is not confined to federal systems; it also appears within a single and theoretically centralized hierarchy. ${ }^{8}$ Within the states themselves there are jealousies and factional fights among staffs supposedly loyal to the same chief executive. Likewise, cooperation between lower federal officials in different departments is often difficult to secure.' Indeed, jurisdictional dispute seems to be a disease of all administration. No statute could define the powers of officials so precisely as to avoid all controversy. ${ }^{\text {10 }}$ Jurisdictional squabbles merely reflect the struggle for power always present in a community. It is doubtful whether federalism really adds to, although it often dramatizes, what is an inevitable inefficiency and struggle. On the other hand, it is probably even easier to integrate state than national officials, since they live in the same community, share in consequence some of the same purposes, and are nearer to the same supervisory head.

Since each state in exercise of its federal right maintains a separate educational system, federalism makes it difficult to achieve the level of professional training for officials that is possible under a uniform system for their training, their entry into a single service, and their promotion within it. ${ }^{\mathrm{xx}}$ Diverse training is now pursued to meet the differing requirements of the civil service commissions. "I2 "In-service" training offers a partial solution both for the inadequacies of heterogeneous preparation for entry into the service, and for the absence of a professional attitude not

8 For striking evidence of lack of co-ordination in the exceptionally centralized French administrative hierarchy, see Sharp, The French Civil Service 32-42 (I93I). Jurisdictional disputes between the administrative courts and the regular judiciary are frequent. See Riesenfeld, The French System of Administrative Justice: A Model for American Law?, 18 B.U.L. Rev. 48, 75-82, 7I5, 744, 747 (1938).

9 For years, the Labor and State Departments refused to co-operate in their respective jurisdictions over immigration. A recent committee, headed by Professor Marshall Dimock (now Assistant Secretary of Labor), has at last secured a uniform policy. President Roosevelt's various co-ordinators have attempted, without notable success, to straighten out such jurisdictional issues.

ro Under the British India Act of 1935 , the Governor-General is given power to decide ad hoc whether certain subjects should fall within the jurisdiction of the provincial or the central governments. See Report of Joint Committee on Indian Constitutional Reform, Sess. I933-4; H.L. $6, \S 55$.

"This problem, like other problems of federalism, is parodied in less excusable form in conflicts within the states themselves, due to the multifariousness of local subdivisions of all sorts.

12 The Commission of Inquiry on Public Service Personnel recommended co-operation between federal and state personnel administrations in joint use of eligible lists and joint civil service examinations. See Better Government Personnel 7 (I925). 
acquired by university graduate study..$^{13}$ Even so, well-trained men are not likely to enter the service of a smaller state, where they will lack professional associations and may find themselves up a blind alley as far as promotion is concerned. To some degree, this price of federalism can be minimized by frequent transfer of men from state to national service and vice versa, and through the many professional associations which have a national scope. ${ }^{14}$ It seems, therefore, that federalism adds no insuperable obstacles to the inherent difficulties of operating an efficient government administration.

The positive function of federalism, like that of any form of regional decentralization, is to make government more responsible. Officials are constantly engaged in adapting statutes to needs encountered in administration. Even in a dictatorship, power does not operate only from the top down, and in relatively democratic societies, close relationships between officials and citizens are essential. Federalism accommodates this relation somewhat better than other forms of decentralization. ${ }^{15}$ From the national point of view, federalism permits economic representation for the heterogeneity of interests caused by regional differences. From the local point of view, it compels some officials to be residents of the state in which they work, to be aware of local needs, and to fulfil these needs if they desire promotion. ${ }^{16}$ They are not emissaries from a distant capital, looking to it for orders, for inspiration, and for a career..$^{17}$ The result is that these officials gain experience and a feeling of personal responsibility through contact with their regional group, while the citizens, too, participate in government through that contact. Despite modern advances in communi-

${ }^{23}$ In other words, once the men are in the government service (often on the basis of prior professional training) they will then receive further training under the auspices of their particular department (as in the case of the training school of the Federal Department of Agriculture) or by means of fellowships at institutions like the Harvard Graduate School of Public Administration, open only to men already in the government.

14 For a list of these associations, see Graves, Uniform State Action, App. B (I934); for discussion, see ibid., at 77-265.

Is Compared to the press of European countries, American newspapers were extremely provincial until the $\mathrm{New}$ Deal diminished the importance of federalism. They tended to be non-partisan in national affairs, but partisan, or at least concerned in, local disputes. Of course, other factors besides federalism account for this differentiation, with its obvious significance for the problem of local responsibility.

${ }^{26}$ With both the increase in federal power due to spending, which compels party loyalty in the congressman to secure appropriations for his district, and a concomitant decrease in the extent of federal patronage allowed to congressmen due to civil service extensions, the retention of seats of local political power becomes particularly vital in preserving the looseness of our party structure. See pp. 670-5 infra.

17 Administrators who live in Washington tend to associate only with other administrators and to develop an extreme view of the importance of their particular mission. 
cation, this living together, this geographical closeness, remains important and vital for responsibility in a democracy.

Few maintain that the states are ideal regions for federal decentralization. Indeed, it is rather difficult even on paper to visualize what such ideal regions would be, since the areas comprising a "region" may differ for different purposes. But with the boundaries such as they are, a network of customs and devices have evolved to assure the necessary cooperation between the states and the federal government, and among the states themselves. ${ }^{x}$ Of the devices securing a minimum of national uniformity, the grant-in-aid is most important. Transfer of men between the services also helps to induce co-operation and to circulate improvements. The Interstate Commerce Commission and other federal agencies have made progress in securing state support by taking state officials into conference where local as well as national issues are involved. County extension agents are state as well as federal agricultural officers. Other devices remain to be exploited, notably state administration of federal law.

On the whole, there is value in the competition of parallel services. Each acts as a check on the corruption of the other; and competition for the citizen's allegiance adds another useful pluralism to our political life, and helps to curb the dangerous worship of the "State." With intelligence and goodwill, the obstacles to a rational system of administration that federalism presents may be minimized while the advantages of federalism in producing administrative responsibility are preserved.

\section{SEPARATION OF POWERS}

The constitutional separation of powers of the national government divides the power to govern into three branches: the legislative, executive, and judicial. Buck-passing, jurisdictional disputes, and other inefficiencies seen in federalism and its separation of powers are to be found in this national separation of powers as well. ${ }^{x}$ Consequently, many look with envy toward some unitary system; others insist that the separation of powers is dying, if not already dead. But the separation of powers is not simply a legal dogma which is peculiar to the United States. It is in part the legal crystallization of a simple psychological hypothesis which supposes that human beings engage in three more or less distinguishable types

${ }^{28}$ For a survey of these devices, see Clark, The Rise of a New Federalism (r938).

19 Compare the problem of responsibility in India under the system of diarchy, whereby the British viceroy reserved certain important powers. The Joint Committee on Indian Constitutional Reform pointed out that since Indian native politicians lacked complete responsibility, they refused to accept any responsibility at all and "passed the buck" on to the viceroy because of his reserved powers. See Report of Joint Committee on Indian Constitutional Reform, Sess. ז933-4; H.L. $6, \S$ I7. 
of mental process: rule-making, administering, and judging. While it is possible, if the psychological hypothesis is sound, to distinguish in a general fashion these three types of mental process, separation of these functions is arbitrary in the individual, and artificial to some extent in an administration which engages in all three activities.

The decline of the doctrine of separation of powers is usually argued from the example of the independent agencies and commissions, because in them a certain commingling of legislative, executive, and judicial functions is needed and has been permitted. But in fact, the agencies differ greatly from each other in the amount of the various powers they possess. The duties of the Interstate Commerce Commission are largely legislative, those of the Tennessee Valley Authority are largely executive, while those of the Labor Board are mainly judicial. Moreover, the separation of powers, owing to its psychological basis, tends to reappear within the agencies themselves. Different personnel are likely to be allocated to the different tasks. This tendency to specialize is reinforced by the nature of the supervision over the work of the agencies. On their judicial side, they are subject to the control of the courts, and thus resemble inferior courts. In their rule-making sphere, they are supervised by both the courts and Congress. They are also responsible to Congress for annual recommendations, often accompanied by bill-drafting. Sometimes they conduct investigations under Congressional direction. On the executive side, however, there is no organized system of review. A problem of supervision like that which has been seen to harass the hierarchical control of a federal system is thus presented.

For three decades, successive presidents have struggled with this problem of supervision. Not being permitted by law to supervise the executive acts of the independent agencies, they have sought to assert control through devious channels. Coolidge misused the appointing power in his battles with the Tariff Commission. Roosevelt short-circuited the Tariff Commission by means of the Trade Agreements Act, openly putting tariffmaking into executive hands. Several presidents have sought to establish an absolute power to discharge commissioners as a necessary means of supervision. Chief Justice Taft, who as President had failed to carry his reorganization plans through Congress, held in Myers v. United Stales ${ }^{20}$ that President Wilson could discharge a first-class postmaster who had been appointed with the advice and consent of the Senate. More important was his dictum that the President could not be deprived under the Constitution of the right to discharge members of the "independent"

${ }^{30} 272$ U.S. 52 (1926). 
agencies. ${ }^{2 I}$ The Constitution charges the President with the faithful execution of the laws; the power to discharge is necessary for that execution; hence the President can discharge any official. So ran Taft's simple syllogism, ignoring the possibility that, as ample experience demonstrates, the unlimited power to discharge is not essential to adequate administrative supervision..$^{22}$ Roosevelt brought the issue to the courts again in Humphrey's Exec'r v. United States ${ }^{23}$ by discharging a Federal Trade Commissioner, relying on the dictum of Taft in the Myers case. But the Supreme Court held that the commission was a quasi-judicial body and, as such, entitled to independence of tenure. ${ }^{24}$ The Court relied in part on statutory interpretation, and perhaps as a matter of statutory interpretation it could be said that Congress set up the commission as it did to insure independence of tenure. Yet Congress had not been operating on any consistent principle, and independence may have been due to distrust of the Department of Justice. Similarly, the independence of the Social Security Board seems to have been intended as a rebuke to the Secretary of Labor.

The dogmatic attitude of the Court in the Myers and Humphrey's cases finds its counterpart in the report of the President's Committee on Administrative Management. The committee thought that the setting up of independent agencies was a violation of the constitutional separation of powers, a view slightly irrelevant at this late date even if true. The committee, without examining the actual extent of the President's control, took offense at the anarchic-seeming lot of independent boards, corporations, commissions, and authorities. ${ }^{25}$ Since the President has not only ten cabinet officers to co-ordinate, but over a hundred agencies, most of them topped not by individuals but by hydra-headed boards of three or more, the committee concluded that the independent commissions should be grouped under the cabinet officers.

As with federalism, lack of administrative co-ordination is rendered dramatic by open jurisdictional disputes between the cabinet and the

ax Ibid., at 564 .

${ }_{22}$ Removal for cause is, however, a valuable disciplinary control. See Cushman, The Constitutional Status of the Independent Regulatory Commissions, 24 Corn. L.Q. 163, 18I-5 (I939); cf. ibid., at 170.

23295 U.S. 602 (I935).

34 The Federal Trade Commission is not only a judicial but an executive body, for with a limited budget it must decide to prosecute certain offenders and not others.

25 For the kind of inquiry needed, see, e.g., N.Y. Times, April 22, 1939, at 2I: "The law requires that the commission [SEC] name its chairman, although in practice it has respected the wishes of the White House in this connection." 
commissions. In order to minimize disputes, the President's Committee suggested a blueprint of a unitary plan, the stock remedy of the opponents of federalism. Such a remedy seems suspicious. Even from the point of view of business management, which was the committee's touchstone, it may be wise to confine the President within the enormous sphere where his jurisdiction is now legally supreme, lest he spread his efforts too thinly. Moreover, a power to hire and fire is not sufficient to secure a unified and responsible direction of the federal hierarchy since even now there is an indication that the President's administrative task is unmanageable. ${ }^{26}$ Furthermore, there is evidence that the independence of an administrative agency helps to attract competent personnel from private life. ${ }^{27}$ And at least where large capital investments are concerned (e.g., SEC, FPC, and FCC), some continuity of individual policy, protected but not insured by independence, may be preferable to temporary co-ordination of all policies with the four-year plan of a particular administration, even assuming co-ordination to be feasible. Apart from managerial considerations, a judgment on the desirability of greater presidential control turns on one's hope of good presidents or fear of bad ones. Despite these criticisms, the committee's program for the independent agencies deserved further study and experiment. ${ }^{28}$

The familiar complaint that federal commissions act both as prosecutor and judge in their own cases looks for theoretical support to the doctrine of separation of powers. ${ }^{29}$ Here again it is important to conceive of the sep-

${ }^{26}$ It seems doubtful, e.g., whether President Roosevelt has had set views as to policy in the transportation field, despite his appointment of a federal "co-ordinator"; cf. Earnshaw, The Federal Coördinator of Transportation, $26 \mathrm{Ky}$. L.J. I82, I86, 228, 324 (I938).

${ }^{27}$ See Landis, The Administrative Process ( 1938 ); IV Sharfman, The Interstate Commerce Commission 258-74, 347-8 (I937). On the other hand, is it possible that the "wrong" type of civil servant is attracted by the name-on-door type of prestige attached to the independent agencies?

${ }^{28}$ An alternative suggestion to the reshuffling proposed by the President's Committee would give the President power to issue executive orders binding on all officials in the sphere of their administrative duties. See Friedrich, op. cit. supra note 6, at 5I-4. Professor Cushman differs, believing compliance with executive orders cannot be secured unless the President may remove the members of the independent commissions. See The Problems of the Independent Regulatory Commissions, in The President's Committee on Administrative Management, Report with Special Studies 203, 235 (1937).

A draft of the Civil Aeronautics Bill, never enacted, provided: "The exercise and performance of the powers and duties of the Authority which are not subject to review by courts of law shall be subject to the general direction of the President." Quoted in Cushman, The Constitutional Status of the Independent Regulatory Commissions, 24 Corn. L.Q. I63, I77 (I939). See also ibid., at $182-3$.

29 On the personal contacts existing between commissions and expert witnesses for the government, see, e.g., Newell, Experiences of an Expert Witness before Administrative 
aration of powers as a psychological hypothesis about administration rather than as a legal doctrine. Where the identical man does not both bring cases and decide them, a certain amount of separation can and does exist. A valid distinction can perhaps be drawn between agencies whose purposes are more or less accepted by the general community, agencies like the Interstate Commerce Commission and Maritime Commission, and agencies which bear the administrative task of promoting policies on which all sections of the community are not agreed, agencies like the Labor Board and Federal Trade Commission. But in truth, each agency presents a different problem. The character of its main task, the trained specialization of its personnel, the length and traditions of its establishment, all bear on the relative unity or relative separation of its powers.

Separation within the independent agencies is generally considered desirable. It may be that in the larger sphere of government, separation fosters competence by making officials specialize as judges, legislators, or executives. The mutual checks furnished by the three independent branches, with their somewhat different sources of appointment and tenures of office, clearly aid responsibility. But when that separation is imitated by the independent agencies, specialization and responsibility assume somewhat different aspects. ${ }^{30}$ These agencies are already specialized. They deal with a particular industry, such as transportation or coal mining, or a specific problem common to all industries, such as labor practices or trade practices. There is value here in an amalgamation of powers, since judges who are also prosecutors are more likely to achieve consistent interpretative development of the statutory policy, ${ }^{3 \mathrm{I}}$ and legislators who are also administrators will comprehend the possibilities and limits of legislation in their particular field. Moreover, the independent agencies are not truly independent or irresponsible. Review by Congress and the courts keeps them responsible, within limits, in making rules and render-

Tribunals, I6 Ore. L. Rev. 46, 48-9 (1936). Relations between judge and district attorney are often too close for defendant's comfort. The same is true of relations between district attorney and juries.

${ }^{30}$ An illuminating comparison can be made with the municipal corporation against whose union of powers no one has objected. Here division which is geographical, rather than functional, limits the scope of the power, and the necessary check is provided by the supervisory authority of the organs of the state-executive, legislative, and judicial. See Stason, Administrative Tribunals-Organization and Reorganization, 36 Mich. L. Rev. 533, 553 (1938).

${ }^{32}$ In order merely to know the facts so as to be able to adjudicate a simple question, the judge need not be a prosecutor; if he is, the danger arises that he will not permit "the facts" as he knows them to be controverted. Judicial review on the facts is usually narrow. See p. $66_{5}$ infra. 
ing decisions. ${ }^{32}$ Only on the political or executive side can an argument about irresponsibility be made. Perhaps legalization of some modicum of executive control, varying with the nature of the agency's tasks, would bring into the open the now-covert partisan issues. Men of scientific temper in those agencies, most of whose work is objective, may not be sorry to lose final jurisdiction over disturbing political questions. Conversely, a president assured of a direct power over agency activity related to his electoral promises would not need to scrutinize appointees with an eye largely to loyalty, or resort to the various devices with which presidents have "managed" the agencies-devices destructive of morale, as seen in the Tariff Commission. Thus a carefully circumscribed executive review of political decisions might not only obviate the need for an artificial separation of powers within the agencies greater than that demanded by administrative expediency, but might also add to the agencies' competence along judicial and legislative lines. The report of the President's Committee sought to obtain that review by shuffling all the agencies into a cabinet portfolio. A desire for legalistic symmetry obscured the evidence that each agency presents a special case.

\section{RULE OF LAW}

While the constitutional doctrines of federalism and separation of powers divide power between groups of officials, the third division of power defines the rights granted to the official and to the citizen. This division, originating in the Bill of Rights, will be called "the rule of law," although, of course, all three divisions of power are part of the law of the Constitution.

In proceeding from cure to prevention, the development of the rule of law has followed a familiar social pattern. The curative stages have not disappeared, but exist alongside the later preventive ones. The first stage is the traditional rule of law-the personal liability of officials in court for ultra vires acts. Such liability, of course, is not wholly curative, since officials may gradually conform to the decisions that are laid down, thus lending preventive efficacy to the case-law through their anticipations. But the safeguard is more apparent than real. The injured citizen will often lack resources to sue, or it may not be worth his while, as, for example, where he is overcharged a few cents on his electric bill. Usually the

${ }^{2}$ It has been further suggested that administrative adjudication, since later reviewable, should be thought of as a step in the process of forming administrative policy. See Cole, Some Recent Proposals in the Sphere of Administrative Justice, 32 Am. Pol. Sci. Rev. 926-7, 929 (1938). See also Landis, The Administrative Process (1938), for a discussion of this entire problem. 
offending official will be judgment-proof; if he is not, court and jury will be loath to wipe out his personal fortune for acts done in good faith or at the command of his superiors. Furthermore, the fear of personal liability in court hampers officials in acting where they should act in the public interest. ${ }^{33}$ Accordingly, the immunity of the state, and conversely, the liability of its officials, seems to be disappearing, in part through the fiction of calling many new government activities "proprietary." Even so, the imposition of state liability is of small efficacy as an administrative control, because the individual may be irreparably injured before his case can be decided, and because that injury perhaps should be compensated despite the technical legality of the administrative action. ${ }^{34}$

The second stage, judicial review of ultra vires acts either by certiorari or like remedy, or by injunction, carries a great admixture of prevention, but still remains largely remedial. Moreover, judicial review ordinarily furnishes protection only at the fringe of administration, where questions of "law" are involved; the vast discretionary realms do not bow to stare decisis. Where the courts try to scrutinize "the facts" and exercise their own discretion, administration, whether aggressive or complaisant, is likely to be futile. That may be the conscious or unconscious objective of such parental courts. Consequently, judicial review, like the personal liability of officials, has often served to hamper officials in acting where they should act, notably in public utility regulation. But even where courts wish to compel needful action, they lack the necessary techniques for doing so save in the simplest situations. Furthermore, many important questions have long been entirely removed from the scrutiny of courts, for lawyers, when they speak of judicial review, mean review by courts established under Article III of the Constitution, and not by administrative courts or judicial bodies not called courts. Accordingly, judicial review, like the legal liability of officials, seems of vanishing, if not of doubtful, utility as a device for making administration responsible. ${ }^{35}$

The third stage is largely on the preventive side, with minimal curative efficacy. This stage is also a form of judicial review, and its operation is procedurally the same. It differs in that it attempts to correct, not a

33 The official is not liable in a private suit for nonfeasance. See Jennings, Tort Liability of Administrative Officers, 2r Minn. L. Rev. 263, 266-8 (1937).

34 These difficulties have led many to urge adoption of an administrative court modeled on the French Conseil d'Etat. See, e.g., Hart, The President and Federal Administration, in Haines and Dimock, Essays in the Law and Practice of Governmental Administration 47, 79-84 (1935); Thach, The Inadequacies of the Rule of Law, ibid., at 269, 280-6.

${ }^{35}$ Judicial review of administrative rules might be treated as akin to review of specific decisions, or as akin to review of procedural steps. 
single decision of a quasi-judicial agency, but rather the procedure of agencies as a whole. Notice, hearing, the weighing of evidence and argument, the framing of issues, the adoption of an examiner's report-these are the judicial processes which are to be imposed on the administrative, since they are safeguards which are supposed to aid responsible decision. The House of Lords said in Local Government Board v. Arlidge $e^{36}$ that "judicial methods may, in many points of administration, be entirely unsuitable, and produce delays, expenses, and public and private injury." But in the cases of Morgan v. United States, ${ }^{37}$ the Supreme Court, following earlier indications, held that, at least in rate regulation, the Constitution required administrative agencies to adopt procedures which, if not identical with those of courts, were basically similar. Tendencies toward bias and unconsidered action can be checked to a considerable degree by these procedural requirements. Obviously, however, stupid or biased officials can go through the proper motions, and yet make wrong decisions. ${ }^{38}$

The fourth stage of the rule of law deals directly with the problem of assuring the substance of correct and honest decisions, rules, and actions. Like the other three, this last stage makes use of the courts. But they are no longer called in, at the cost of great delay and expense, to penalize irresponsible officials, to curb outrageous misconduct, or even to enforce their procedure through administrative fear of reversals. Instead, they are employed as examples, perhaps our finest examples, of a lawful and responsible administration. They point to the value of attempting to create in other administrations conditions similar to those which control courts. This stage, of course, is wholly preventive; it will relieve no immediate abuses; it points to the future and the long run. Judicial control at all prior stages has been external, a series of taboos. These checks de-

${ }_{36} 6$ [1915] A.C. I20; cf. Errington v. Minister of Health, [1935] I K.B. 249; Short, Administration and the Law, I4 J. Pub. Admin. 30I, 310-I2 (1936); Jennings, Natural Justice, I4 J. Pub. Admin. 332-6 (x936).

${ }_{37} 298$ U.S. 468 ( $(936) ; 304$ U.S. I ( $\left.x_{93} 8\right)$. It has been argued that each type of administrative proceeding involves a different problem. See Fuchs, Symposium on Administrative Law, 9 Am. L. School Rev. I39, I4I-4 (1939); cf. Brown, Symposium on Administrative Law, 9 Am. L. School Rev. I78-80 (r939) (tentatively setting certain general principles of fair hearing). See also Feller, Prospectus for the Further Study of Federal Administrative Law, 47 Yale L.J. $647,659-7 \mathrm{r}\left(\mathrm{r}_{93} 8\right)$.

${ }_{38}$ Of course, most American courts do make an effort to discover a bias which may lie beneath technical correctness. See Cushman, The Constitutional Status of the Independent Regulatory Commissions, 24 Corn. L.Q. I63, I94 (I939). But cf. Marx, Comparative Administrative Law: A Note on Review of Discretion, 87 Univ. Pa. L. Rev. 954 (1939). The procedural rules requiring the administrative adjudicator to make specific findings of fact and conclusions of law to a certain extent do compel objectively responsible judgment, but again only at the judicially-reviewable fringe of administration.

The interesting doctrine of the Conseil d'Etat in annulling actions formally valid but improperly motivated is set forth in Riesenfeld; op. cit. supra note 8, at 425-6. 
signed for savage administrators are not wholly ineffective. But a civilized administration depends upon impregnation of a judicial conscience.

The responsibility of judges does not rest on election or appointment. It rests on publicity, training, and esprit de corps. Publicity means open trials and law reports. Judges must give reasons for their opinions, and their judgments must satisfy not only their superiors, but an informed and organized profession. In this way, they are responsible to standards set out in critical writings by university professors, law institutes, and other professional groups. They are responsible to a judicial tradition of rationality and neutrality which has been built up through the centuries and inculcated in each novitiate by a long course of training. The fraternity of bench and bar keeps the tradition green, and through these efforts, an esprit de corps results. It follows that a promising avenue for the control of an administration is to judicialize its attitude. ${ }^{39}$ The rule of law, in the broadest sense, thus includes not only responsibility before the courts; it implies submission on the part of a professionalized, judicialized administration ${ }^{40}$ to public, predetermined standards, and to objective facts. As government increases its supervision of the economic order, the forces in the social order that support the constitutional divisions of power are concurrently undermined.4x It then becomes all the more important to find and to elaborate these internal restraints on government administration.

39 Safeguards are provided for judges by the existence of the disbarment sanction for lawyers who attempt to exercise ex parte influence on them. See Radin, The Problems of Administrative Law, I5 Ore. L. Rev. I34, I40-2 (r936). See also Radin, The Courts and Administrative Agencies, 23 Calif. Q. Rev. 469, 475-8 (I935). Members of administrative boards have complained to the writer of the embarrassment caused them by lawyers who, to impress clients or opponents with their "influence," would call members by their first names and generally assume an unwarranted intimacy while their cases pended that they would not dare to assume with most courts. Such incidents are hard to avoid without a general change in public attitude as well as in the attitude of the administrator.

40 Arnold, The Symbols of Government 215 (I936): "Ironically enough, the annoying red tape of governmental bureaus is more often than not the result of the efforts of learned men to make them resemble judicial institutions." It is true that officials who are not lawyers are often more legalistic than officials trained in law, but judicialization should not mean treating the "convenient maxim" of stare decisis like the command of res adjudicata, since precedent is only one of many factors to be considered in giving judgment without losing objectivity.

A converse process is the increasing awareness of judges that they are engaged in administration.

${ }^{4 \pi}$ There has been little discussion of the problem of responsibility in a socialized state where all are either managers or work for the managers of a single employer. Even objectivity requires some leverage for its enforcement from outside the profession, and the growth of syndicalism among civil service employees has served to hint at the dangers presented as the state takes over more and more activities. See Friedrich and Cole, Responsible Bureaucracy; A Study of the Swiss Civil Service 87-9 (I932). 
II

Federalism, the separation of powers, and judicial review affect responsibility in the divergent ways that have just been examined. The factors now to be considered arise largely outside of the Constitution.

No one denies that decisions of judges or executives may turn not only on "the facts," but on the temper in which the facts are regarded. Both the exhaustiveness of factual inquiry and the temper of decision are subject to a modicum of control. A basic control is free, informed, and influential criticism. ${ }^{42}$ The problem of informed criticism is partly a problem of publicity. Judges and lawyers, by virtue of public hearings, law reports, law journals, and newspapers, have formed the habit of enduring publication of their opinions and proceedings, and criticism thereon. The attempt to extend throughout the government service the same kind of publicity may assist the development of a professional esprit de corps, a pride in sound, technical work. ${ }^{43}$ While the legal profession can count on a body of critical judgment based on elaborate rules which are common ground to the profession and esoteric to the laity, administrators, whatever the true factual situation, appear in the public eye less esoteric and more political. The criticism of colleagues may be less infuential in keeping administrators responsible, since there is less common ground and less of a traditional deference to professional criticism. On the other hand, in view of the political nature of administrative decisions, the public is more likely to criticize. The wisdom of increasing criticism from outside the administrative profession is uncertain. The Swedish government administration seems to be conducted successfully with all files open. But the

${ }^{42}$ For criticism to be free, the community must be agreed at least on certain procedural methods for assuring freedom of discussion; for criticism to be influential, the community must not be rent by social conflict so extreme that neither side will listen to the reasoning of the other. See p. 674 infra.

${ }_{43}$ Professional societies and associations are similarly important. See p. 667 supra; Gaus, The Responsibility of Public Administration, in Gaus et al., The Frontiers of Public Administration 39-40 (1936); Dimock, Forms of Control Over Administrative Action, in Haines and Dimock, Essays on the Law and Practice of Governmental Administration 287, 308-r4, 321 (x935). Mosher, The Profession of Public Service, 32 Am. Pol. Sci. Rev. 332, 335-8 (I938), advocates professionalization of government work as such. More desirable, in my opinion, is professionalization along position lines, as in the case of judges who are members of the bench-and-bar. See Meriam, Public Service-Occupation or Industry?, $32 \mathrm{Am}$. Pol. Sci. Rev. $7 \mathrm{I} 8,720-I$ ( $\left.\mathrm{I}_{93} 8\right)$ for an answer to Mosher. Responsibility is assisted by consultation of professionals in and out of government, p. 669 infra, while administrative syndicalism increases the fear of government "bureaucracy." Nonetheless, it has assisted the growth of professionalization. For the situation in France, see Sharp, The French Civil Service 495-500 (193I); for Switzerland, see Friedrich and Cole, Responsible Bureaucracy; A Study of the Swiss Civil Service c. V and pp. 87-9 (r932). 
House of Lords in Local Government Board v. Arlidge ${ }^{44}$ thought that publicity of official files would be disrupting to confidential and conscientious work. ${ }^{45}$ Such publicity might tempt an administration to resort to ways of covering up what was actually being done. All professional groups have inclinations to present an obscurantist front.

Consultation with the interested members of the public is to the administrative process what argument is to the court. All highly developed countries are experimenting with advisory councils for bringing together the administrators and the persons mainly affected by administration. Federalism offers opportunities for consultation along regional lines, and the independent agencies isolate a corps of specialists within the government and provide for easy (perhaps excessively easy) access to and from the outside. Consultation, however, is a method of decentralizing administration, and it fosters a democratic participation in government which is more vital than elections. ${ }^{46}$ It can be developed into a powerful instrument for the assurance of responsibility. By means of consultation, offcials are provided with facts, including the views of the regulated group, and must act objectively on the basis of these facts if the informed opinion of the interested group is to be satisfied. In a sense, consultation also turns the citizens who are consulted into officials pro tem, made soberly responsible by the fact that they are likely to be listened to if their advice has weight.

If officials are to base their actions on objective facts, it is clear that the

$$
14 \text { [rgr5] A.C. I20. }
$$

is No evidence for this position was found after a careful weighing of the publicity problem. See Jaffe, Invective and Investigation in Administrative Law, 52 Harv. L. Rev. I20I, I2II-I 5 (1939).

It must, of course, not be forgotten in discussing Local Government Board v. Arlidge, [rgr5] A.C. r20, that questions directed to the ministers in the House of Commons are a very effective check on administrative abuse. Even members of the party in power, since they champion their constituents in this way rather than by patronage, avail themselves of this publicity weapon. See Elliott's introduction to Stout, Public Service in Great Britain xv-xvi (1938).

In France the weapon is sometimes abused. Embarrassing questions are withheld for a quid pro quo, the information on which the questions are based being learned through the deputy's friends in the administration. See Sharp, The French Civil Service 77-8, 544 (I93I). There is, one may guess, a relation between this "spy" system and "the extraordinary secretiveness and reluctance to furnish information about the public service which typifies so many French government offices," ibid., at 442-3, 450. In France one may resort to the official files in attacking an administrative decision on the ground of improper motivation.

${ }^{6}$ Many persons who have considered the problem are aware of the need for supplementing the dull regularity of elections with more extensive public participation and responsibility. See, e.g., Lynd, Knowledge for What?, 212-I3 (I939); Merriam, Prologue to Politics 23 (I939): "The organization of consent is the greatest problem of our day." 
ability to master facts is essential for responsibility. Able officials may not be responsible; stupid ones cannot be. The question arises as to what conditions aid in securing ability in government. The belief was stated previously that constitutional limitations were not the causes of American deficiencies. Specialization is the basis of efficiency in administration. Moreover, specialization connotes the professional attitude, which is itself a pillar of responsibility. But specialization requires an expensive and lengthy training which men will undertake only when promised a return on their investment in the form of a career. For this, they must be given a fair and equal chance to enter the government service. They must be promised security of pay and tenure and the possibility of promotion. To some extent, then, efficiency and responsibility both depend on objective personnel practices-in short, on civil service. Not only were the forces absent in the United States which were responsible in Europe for the creation of a civil service, but adverse factors peculiarly American were present. The frontier spirit supported Jackson's insistence on rotation in office, ${ }^{47}$ since one man was as likely to be expert as the next, and it fostered an extreme individualism resentful of hierarchical discipline. The melting pot contributed to the development of corrupt urban machines, and led to the feeling that each racial and religious group, irrespective of merit, is entitled to public jobs in numerical or more than numerical proportion. Veteran's preference in the civil service, ruinous to any merit system, seems more extensive in America than elsewhere. $4^{8}$ More extensive also in America is the destructive and fruitless attack upon "bureaucracy," which makes many Americans believe that the better our government service, the worse it will be for them, ${ }^{49}$ a view which lowers official morale and authority, and dissuades first-class persons from entering upon

47 England never knew rotation in office, even in the old patronage days. The American revolutionists, who had seen colonial governors treat their office as private property, and who feared the tyranny of an official caste, made rotation a principle long before Jackson. See Brinser, Our Government-For Spoils or Service?, 2-3 (I936).

${ }^{8} \mathrm{~A}$ similar handicap is the popular American notion that the public payroll is a place for charity-often related to patronage but sometimes simply eleemosynary in motivation.

49 "Bureaucracy," which is simply a derogatory name for "administration," appears of course in any large organization, whether a bricklayer's union, a telephone company, or a university. In every land there is a vast storehouse of petty grievances against petty officials. "To complain about the mysterious intricacies of official form seems a patriotic obligation for Frenchmen," Sharp, The French Civil Service 450 (I93I). In other nations patriotism makes the same demand. See opinions of Chief Justice Hughes in Morgan v. United States, 298 U.S. 468, 47I-82 (I936); Morgan v. United States, 304 U.S. I, I3-22 (I938); St. Joseph Stock Yards Co. v. United States, 298 U.S. 38, 45-72 (1936). See also Reports of the American Bar Association's Special Committee on Administrative Law. For the cynical French attitude, see Sharp, op. cit. 432-59; for the sensible Swiss approach, see Friedrich, op. cit. supra note 6. 
a government career..$^{\circ}$ Furthermore, the government service has had to compete for talent and survival with two even more powerful services: that of business, exciting, rich, and dominant, and that of our party machines, fierce, disciplined, and fat.

These imposing handicaps to the construction of an efficient government service are not wholly negative. The average American does remain versatile: the Yankee jack-of-all-trades appeared to advantage in the war administration; he has done so again in the government's fight against depression. Again, diverse racial groups, although in one respect upsetting the merit system by their claims and racial nepotism, in another respect nurture a competitive patriotism imbued with loyalty to the United States and anxious for a chance to prove it by actual service. Our many religious groups compete not only for public recognition in the form of jobs, but also to preserve the norms of duty and individual moral responsibility without which the intellectual concept of objective responsibility would be defenseless. Business, supposedly the rival of government, generously makes its experts, techniques, and resources available to the "enemy." "5r The two-party system, machine-entrenched, serves to forestall that irreconcilable division into classes which would quickly transform an embracing objectivity into a class intransigence. Of all the obstacles to efficient governmental service listed, only veteran's preference ${ }^{52}$ and the self-defeating complaint against "bureaucracy"s3 are unadulterated evils.

Civil service reform, until recently, has regarded its function as negatively coping with these obstacles. It has protected six hundred thousand

${ }^{50}$ Though government regulation has a respectably long tradition in the United States, still the popular feeling as to what government ought not to do has had its effect in destroying administrative morale and drawing capable men into socially approved businesses rather than into unapproved or unnoticed government offices engaged in regulating business.

sx And vice versa. Although the approach here is to administrative problems within the governmental frame of reference, a caveat against making any essential distinctions between government administration and business administration should be kept in mind throughout. It may be permissible to generalize that in the United States, business can learn from government something about attaining responsibility through dividing power, while government can learn from business about achieving competence, now sometimes thwarted by the excess of responsibility that appears to outsiders as "red tape."

52 An asset, probably, is the absence in America of compulsory military service, which tends to innoculate officials at the same time both with an attitude of deadening deference to regulations and with an attitude of arrogance toward the mere unofficial citizen.

53 Not only does denunciation help to produce the evils complained of, see note 50 supra, but it is associated with complaisance toward the actual processes of administration as indicated, for instance, in the failure to remove the unjust and anachronistic immunity of the "bureaucracy" from tort actions. 
lower federal, and many state, officials from the spoilsman; it has classified their pay and made permanent their tenure. ${ }^{54}$ Permanence of this sort bears directly on responsibility by furnishing the security necessary to disinterested judgment. But permanent tenure can serve additional ends. It permits the creation of standards of entry and promotion which prompt good men to specialize in government work. Such pre-entry specialization, moreover, can be continued after entry by life-time association with the job. With this in mind, civil service reform is finally beginning to turn to positive measures for attracting bright young men into the top positions in government administration, and for keeping them permanently there in spite of the lures of private industry or of party service in elective jobs.

This will be an uphill fight, for while permanency is generally thought desirable for a judiciary, in the other spheres of government, no agreement has been reached as to its value. Those opposed to permanence are on the one hand politicians, and on the other hand disinterested progressives who are more concerned about the general social views of a candidate for office than with his specialized training. Each of these two groups, in its own way, denies the existence or the value of objective responsibility. They are right to a degree: objectivity is a goal, capable of only very limited realization, and permanence of tenure does not guarantee its pursuit or partial attainment, since there are many other hazards to rationality besides the simple fear of losing one's job. But the existence of these other hazards, controllable with difficulty if at all, does not seem to be an argument against elimination of the hazard of job-insecurity which can be controlled.

Politicians profess to believe that the only proper kind of responsibility is elective. They have been insisting, since even before Jackson's day, that permanent tenure was incompatible with democratic government, and that only a new group of incumbents chosen freshly from the people every year or so would have their ears attuned to the popular will. But in truth, it would not be practical to vote for each of the three million government officials; even when we do vote, the choosing is usually by party bosses, and the responsibility is to them for favors given and favors expected. Moreover, the popular will which politicians create or rely on is not desirous of settling technical issues. The people have wants, not reme-

54 The evident dangers of tenure without corresponding efforts to retain only good men and to eliminate incapable men are pointed out by the Commission of Inquiry on Public Service Personnel, Better Government Personnel r9-20, 50-I (r935). The work of the Federal Civil Service Commission is critically appraised from this point of view in Reeves and David, Personnel Administration in the Federal Service, in President's Committee on Administrative Management, Report with Special Studies 55, 78-84 (I937). 
dies, and they ask of government only that it satisfy those wants. Administration bears the responsibility for satisfaction, and it must, therefore, be in limited degree objective. But when entry and promotion in the government service are under the control of patronage, specialization and, consequently, objectivity are thwarted.

While the attack on civil service by party bosses is discredited, and usually furtive, a defensible position is that of progressive critics who fear that a permanent, and concededly able, government service will not be sufficiently flexible-will not loyally support new government ventures, indeed, may sabotage them..$^{55}$ Undoubtedly, there is a need for a limited control of a permanent officialdom by elective or appointive higher-ups as a check on the power of independent civil servants. A democracy cannot rely solely on the experts' objective responsibility to facts, not only because of differences in social views, but also because the normal administrative evils of red tape and jurisdictional dispute require elective supervision..$^{6}$ Nevertheless, one can be fairly certain that American government will fail to cope with change if its officials are amateur, badly trained, and insecure; permanency, therefore, is essential, and its concomitant inflexibility can be controlled by weapons involving neither the demoralization of dismissal nor the abuses of control by pressure politics. Promotion, with no top posts excluded, is the most potent of those positive weapons of hierarchical management; transfers, fines, and demotions are some of the possible disciplines which have been employed successfully in Europe, but which have not been adequately investigated in the United States.

A third and probably the most troublesome attack on civil service is seldom if ever made, either by politicians or progressives. That attack is

ss In a letter to President Roosevelt, May 17, 1938, Mr. Amos Pinchot reported a conversation with Mr. Thomas G. Corcoran over the latter's offer of a directorate on the RFC to Mr. Pinchot. The latter said he lacked the training and experience requisite for such a post. "Mr. Corcoran replied that, so far as training and experience were concerned, I need not worry. All that was required was an obstinate man who would stand up in the meetings of the Reconstruction Finance Board and oppose the policies of the chairman, Mr. Jesse Jones, who, he explained, was disposing of government funds in a stingy fashion," 83 Cong. Rec., May 23, r938, at 9569 .

The point has been made that the civil service acts as the umpire between interest groups. See Finer, Civil Service, 3 Encyc. Soc. Sci. 515 (1930). As umpire, permanent tenure should be assured civil servants, but the difficulty is that the civil service is itself an interest group.

${ }^{56}$ When the objectives of the depression-born agencies come to be accepted, permanent officials will not be likely to resist the policies of elected chiefs, and promotional talent will no longer seem a more important requisite for office than specialized training and expreience. Moreover, the mutual dependence of politician and civil servant prevents continued exploitation by the latter of the technical helplessness of the former. 
premised on the value of our two-party system in dulling the edge of class and sectional conflict, and thus preserving the atmosphere of rational discussion and criticism which supports judicialized administration. Our parties have vague and catholic appeals, but their cement, other than idealism, is in part tradition and in part jobs for loyal party workers. ${ }^{57}$ Civil service reformers are anxious to have principle and not patronage govern the conduct of elections, but principle may split our parties into blocs, exclusive and intransigent. Moreover, a candidate's electoral support, if not wholly idealistic, must rest on his personal wealth or service to the lobbies if his power to secure a following by patronage is removed..$^{8}$ In the necessary choice of evils, some patronage should be retained. A minimum of interference with a specialized career service might be achieved if the many lower government posts, now those most often under civil service, were left within the realm of spoils. Also, the higher administrative positions should change with waves of popular feeling, not because patronage is needed there, but because the very broadest issues of politics are rarely capable of reduction to sufficiently objective terms to be safely controllable by non-electoral responsibility. ${ }^{59}$ But all the intermedi-

57 See also Report of Joint Committee on Indian Constitutional Reform, Sess. I933-4; H.L. $6, \S \S 20-4$, setting out the ideological conflicts of religion, race, and caste which complicate the introduction of British democratic and bureaucratic methods into India. Neither patronage nor propaganda are of much use in promoting smoother operation of government when the sole important fact is whether or not one is, say, a Parsee or a Brahmin, and all other positions follow from that fundamental one.

${ }^{8}$ See Herring, The Future of Patronage, $x_{4}$ Va. Q. Rev. 44, 46-8 (Winter, I938). The value of the President's patronage power as a curb on sectional and class interests in Congress has often been observed. See Lippmann, Public Opinion 285, 29I-2 (1932).

Perhaps the cause of patronage is now a lost cause, at least in the federal government. No idealists battle for it. But see Cole, The "Merit System" Again, 3I Am. Pol. Sci. Rev. 695 (I937). And, if the above analysis is correct, arguments over the New Deal, splitting the electorate into income groups, displaces patronage as a partisan motivation. The President is likely to increase his power, at the expense of Congress, by eliminating patronage in those fields, such as the appointing of postmen, where unbreakable tradition has assigned the job of parcelling to the individual representatives from the district concerned. The argument is often put forward that the legislator's time is wasted on patronage matters. But there are more socially harmful ways of representing a district than securing appointments, notably the cajoling of official decisions for individual or corporate constituents before the various federal agencies.

s9 There is the additional point that high officials are usually anxious to have at least a small "staff" on whose personal friendship or loyalty they can rely, and that their efficiency will be hampered by too rigorous adherence to selection of their immediate subordinates by an independent agency. 
ate posts, as high as bureau chiefs and the assistant secretaries, might be filled according to competence under the merit system..$^{\circ}$

The words "competence" and "merit system," however, hide the difficulties of determining what administrative ability is (apart from special scientific techniques), and of how it may be discovered and developed, although the words do indicate an effort to approach the personnel problem as objectively as experience permits. The problem has been placed, like most hard ones, in the lap of the American educational system, and various tentative solutions have been put forth by universities. Meanwhile, it is clear that the internal judicialization of administration requires not only the elaborate education of administrators, but also education of those with whom they deal. Officials today are likely to encounter the Constitution and the law only in attacks from lawyers and in rebuffs from courts. Then the law may seem an arbitrary limit, rather than a key to the method (as well as the formal basis) of all official work. For the official feels that the legal profession, trained in the traditional case-law, is prejudiced from the start against legislation and government administration. Lawyers are apt to raise the pointless cry against "bureaucracy" and to expect that objective responsibility is only possible from courts. The inner judicialization of administration cannot thrive in such an atmosphere of mutual incomprehension and distrust. ${ }^{6 x}$

${ }^{60}$ This is the position taken by the President's Committee on Administrative Management, in the Report with Special Studies 8-9 (r937); see Reeves and David, Personnel Administration in the Federal Service, ibid., at 55, I2I-2. Moreover, the needs of a career service as a prerequisite to promotion to high posts, which the report also stresses, outweigh the dangers of popularly unresponsive policy-formation by permanent career officials.

6x Dickinson saw this clearly. He concluded Administrative Justice and the Supremacy of the Law in the United States (I927) with a chapter on legal education. Many of his suggestions for bringing more sacial science training into law and pre-law work have been accepted. The recently instituted courses in administrative law are part of this movement, but they are all too likely to be courses in judicial review in the narrow sense.

See Rheinstein, Law Faculties and Law Schools. A Comparison of Legal Education in the United States and Germany, [I938] Wis. L. Rev. 5, 26-8. American private education is not likely to adopt the state-fostered Continental system which gives a broad social science training to lawyers, judges, and civil servants. But law school efforts along the lines outlined by Dickinson can proceed simultaneously with the efforts of schools of public administration to sensitize their students to a broad range of law. 